\title{
A New Trans-Acting Modulator of Fetal Hemoglobin?
}

\author{
Martin H. Steinberg \\ Boston University School of Medicine, Boston, MA, USA
}

Polypeptides of the human hemoglobin $(\mathrm{Hb})$ tetramer are encoded in the $\beta$-globin gene cluster on chromosome $11 \mathrm{p} 15.5$ and the $\alpha$-globin gene cluster on chromosome 16 p16 ter. From embryonic development, through fetal life, and into adulthood, switches in gene expression in these clusters specify the synthesis of 6 different hemoglobin tetramers, each functionally suited for its developmental stage. Many mutations affect these genes and consequently the structure and function of their protein products. Among them are the $\beta$-globin gene $(H B B)$ sickle $\mathrm{Hb}(\mathrm{E} 7 \mathrm{~V} ; \mathrm{HbS})$ mutation and the many mutations accounting for $\beta$-thalassemia. Together, sickle cell anemia (HbS homozygosity; $\alpha_{2} \beta_{2}{ }_{2}$ ) and $\beta$-thalassemia are mankind's most common Mendelian diseases. Within the $\beta$-globin gene cluster are the $\gamma$-globin genes (HBG2 and $H B G 1$ ). Increasing their expression is a potential "cure" for these disorders. Fetal $\mathrm{Hb}(\mathrm{HbF})$, a tetramer of $\alpha$ - and $\gamma$-globin chains $\left(\alpha_{2} \gamma_{2}\right)$, can prevent the polymerization of $\mathrm{HbS}$, the proximate cause of sickle cell anemia, and $\mathrm{HbF}$ also compensates for the lack of $\beta$-globin and normal $\mathrm{HbA}\left(\alpha_{2} \beta_{2}\right)$ in $\beta$-thalassemia. A detailed understanding of the regulation of $\mathrm{HbF}$ gene expression could suggest therapeutic approaches to inducing increased $\mathrm{HbF}$ gene expression.

\section{KARGER}

() 2018 S. Karger AG, Basel

E-Mail karger@karger.com

www.karger.com/aha
As the $\mathrm{HbS}$ gene spread throughout Africa, the Middle East and India, following its possible origin during the Wet Sahara era about 7,000 years ago, its regional expansion became associated with 5 different genetic backgrounds, or haplotypes [1]. Each HbS gene haplotype has a characteristic level of $\mathrm{HbF}$ [2]. A loose association is present between the level of the $\mathrm{HbF}$ characteristic of a haplotype and the clinical severity of patients with this haplotype. Individuals with the Central African Republic or Bantu haplotype typically have the lowest $\mathrm{HbF}$ of all haplotypes (approx. 5\%) and the most severe disease; patients with the Arab Indian (AI) haplotype have the highest $\mathrm{HbF}$ (approx. 20\%) and have the mildest disease. Nevertheless, within any haplotype group, there is a broad dispersion of $\mathrm{HbF}$ levels and clinical features suggesting that regulatory elements that are not linked to the $\mathrm{HbS}$ gene or its haplotype have key roles as modulators of $H B G$ expression.

Three major quantitation trait loci (QTL) are associated with $\mathrm{HbF}$ gene expression. On chromosome $2 \mathrm{p} 16$ is the BCL11A gene. BCL11A is a repressor of HBG expression. Polymorphisms, or SNPs within an erythroid-specific enhancer of BCL11A affect the transcript level and occupancy of its binding domains in the promoters of the

Martin H Steinberg, MD

Boston University School of Medicine

72 East Concord St.

Boston, MA 02118 (USA)

E-Mail mhsteinb@bu.edu 
HbF genes. A bit less is known about actions of the second trans-acting $\mathrm{HbF}$ repressor, $M Y B$, on chromosome $6 \mathrm{q} 23$. A 3-base pair deletion (rs66650371) in the HBS1L-MYB intergenic region is likely to be the functional motif with enhancer-like activity and binding sites for erythroid transcription factors. The third QTL is cis-acting, marked by the SNP rs7482144 that is 158 base pairs upstream of the $H B G 2$ promoter, and affects the expression of this gene only. Together, these QTL accounted for $10-50 \%$ of $\mathrm{HbF}$ variance among different populations [3].

$\mathrm{HbF}$ levels in the AI haplotype of sickle cell anemia are 2 - to 4-fold higher than in other haplotypes. This might be partially explained by a haplotype effect that appears to be unique to Saudi Arabs. Both the African Senegal haplotype, where $\mathrm{HbF}$ levels average about $10 \%$, and the AI haplotype, with $\mathrm{HbF}$ levels near $20 \%$, contain rs7482144. However, homozygosity for minor alleles at rs16912979, rs7119428, and rs7482144 (T/A/T), which are in the major regulatory region of the $H B B$ gene cluster, was present exclusively in the AI haplotype and might represent a functional cis-acting domain modulating HBG2 expression [4]. BCL11A and MYB, the 2 known trans-acting QTL accounted for only $8.8 \%$ of $\mathrm{HbF}$ variance in the AI haplotype population, suggesting the likelihood of other trans-acting elements whose polymorphisms could account for the varying levels of $\mathrm{HbF}$ [5]. To further examine this possibility, whole-genome sequencing was carried out in 14 highly selected adults with the AI haplotype, 7 with $\mathrm{HbF}$ of $8.2 \%$ and 7 with $\mathrm{HbF}$ of 23.5\%. Intronic SNPs (rs4527237, rs35685045; D' = 1) in the gene ANTXR1 on chromosome 2p13, an anthrax toxin receptor, were found to be associated with $\mathrm{HbF}$ [6].
These observations were replicated in 2 cohorts of unselected Saudi AI haplotype homozygotes but not in other sickle cell anemia populations. ANTXR1 variants explained approximately $10 \%$ of $\mathrm{HbF}$ variability compared with $8 \%$ for BCL11A; these 2 genes had independent additive effects on $\mathrm{HbF}$, together accounting for $15 \%$ of its variance. Studies on CD34+ erythroid progenitors and erythroid cells derived from induced pluripotent stem cells suggested that this gene acted as a repressor of $\mathrm{HbF}$ expression.

In the last issue of Acta Haematologica, Al-Ali et al. [7] replicated the original observations in 630 new AI haplotype homozygotes and used different methods of genotyping and analysis, thereby lending further credence to this association. Unfortunately, association provides no information about causation. If ANTXR 1 represses $\mathrm{HbF}$, what is its mechanism? Although BCL11A and ANTXR1 had independent effects on $\mathrm{HbF}$ and there was no linkage disequilibrium between SNPs in ANTXR1 and BCL11A [6]; both genes are on chromosome $2 \mathrm{p}$, albeit in different chromosomal bands. Can there be some long-range interactions between these loci? Is this variant limited to Saudi Arabs? Indian sickle cell anemia patients with the AI haplotype did not show an association of ANTXR1 with $\mathrm{HbF}$; however, only 44 individuals were studied, raising the possibility of a false-negative result. Finally, more than three-quarters of the $\mathrm{HbF}$ variation in the AI haplotype sickle cell anemia remains unexplained and awaits discovery. Increasing $\mathrm{HbF}$ to levels that prevent $\mathrm{HbS}$ polymerization in most sickle erythrocytes will "cure" this disease. Is the ANTXR1 locus another clue to achieving, therapeutically, this goal?

\section{References}

1 Shriner D, Rotimi CM: Whole-genome-sequence-based haplotypes reveal single origin of the sickle allele during the Holocene Wet Phase. Am J Hum Genet 2018;102:547-556.

2 Nagel RL, Fabry ME, Pagnier J, Zohoun I, Wajcman H, Baudin V, Labie D: Hematologically and genetically distinct forms of sickle cell anemia in Africa. The Senegal type and the Benin type. N Engl J Med 1985;312:880884 .
3 Hoban MD, Orkin SH, Bauer DE: Genetic treatment of a molecular disorder: gene therapy approaches to sickle cell disease. Blood 2016;127:839-848.

4 Vathipadiekal V, Alsultan A, Baltrusaitis K, Farrell JJ, Al-Rubaish AM, Al-Muhanna F, et al: Homozygosity for a haplotype of the HBG2-OR51B4 region is exclusive to ArabIndian haplotype sickle cell anemia. Am J Hematol 2016;E308-E311.

5 Ngo D, Bae H, Steinberg MH, Sebastiani P, Solovieff N, Baldwin CT, et al: Fetal hemoglobin in sickle cell anemia: genetic studies of the Arab-Indian haplotype. Blood Cells Mol Dis 2013;51:22-26.
6 Vathipadiekal V, Farrell JJ, Wang S, Edward HL, Shappell H, Al-Rubaish AM, et al: A candidate transacting modulator of fetal hemoglobin gene expression in the Arab-Indian haplotype of sickle cell anemia. Am J Hematol 2016;91:1118-1122.

7 Al-Ali ZA, Fallatah RK, Aljaffer EA: ANTXR1 intronic variants are associated with fetal hemoglobin in Arab-Indian haplotype of sickle cell disease. Acta Haematol 2018, DOI: $10.1159 / 000491688$ 